\title{
Killing mechanism of Listeria monocytogenes in activated macrophages as determined by an improved assay system
}

\author{
S. OHYA* $\dagger, H$. XIONG*, Y. TANABE* $\dagger$, M. ARAKAWA $\dagger$ and M. MITSUYAMA* \\ Departments of *Bacteriology and †Internal Medicine (II), Niigata University School of Medicine, Niigata 951 , \\ Japan
}

\begin{abstract}
Exposure of Listeria monocytogenes to gentamicin $5 \mathrm{mg} / \mathrm{L}$ for $4 \mathrm{~h}$ resulted in the killing of most extracellular bacteria, but had no effect on the survival of bacteria inside macrophages. Higher concentrations of gentamicin caused a reduction in the number of intracellular bacteria. This effect was associated with cellular uptake of gentamicin, but was unaffected by activation of macrophages by interferon- $\gamma$ and lipopolysaccharide. In experiments in which exposure to gentamicin $5 \mathrm{mg} / \mathrm{L}$ for $4 \mathrm{~h}$ was used to kill extracellular bacteria, killing by activated macrophages was impaired when $\mathrm{O}_{2}^{-}$production was inhibited by superoxide dismutase, but not when nitric oxide production was blocked by $N^{G}$-monomethyl-L-arginine. These data suggest that the reactive oxygen intermediates are more important than nitric oxide in the killing of $L$. monocytogenes, at least in macrophages activated in vitro.
\end{abstract}

\section{Introduction}

Listeria monocytogenes is a facultative intracellular pathogen capable of survival and proliferation in macrophages and epithelial cells [1-3]. Entry of $L$. monocytogenes into cells is mediated by the inl $\mathrm{AB}$ and iap genes encoding internalin and protein $\mathrm{p} 60$, respectively $[4,5]$. Soon after internalisation, the bacterium escapes from the endosomal compartments into the cytoplasm by means of the production of listeriolysin $O$ which is a major virulence factor $[6,7]$. Although L. monocytogenes can survive in macrophages of normal mice, bacteria are completely eliminated from infected organs after the establishment of protective immunity [8-10].

It is generally believed that protective immunity depends on the enhancement of intracellular killing of macrophages activated by various cytokines, especially interferon- $\gamma($ IFN $-\gamma)$. When macrophages are stimulated with macrophage-activating factor in vitro, the production of reactive oxygen intermediates is enhanced [11, 12], nitric oxide is induced [13] and phagosomelysosome fusion is facilitated [14]. To investigate the killing of bacteria by macrophages in vitro, antibiotics are used to kill residual extracellular bacteria, and viable

Received 8 April 1997; revised version received 4 July 1997; accepted 7 July 1997.

Corresponding author: Dr S. Ohya. intracellular bacteria are counted at various times during the assay. Gentamicin has often been used to remove extracellular bacteria in such assays, but there is evidence that this antibiotic may affect the viability or growth of intracellular bacteria [15].

The present study investigated the influence of various concentrations of gentamicin on the growth of $L$. monocytogenes inside and outside macrophages. The system developed was then used to examine the role of reactive oxygen intermediates and nitric oxide in the killing of $L$. monocytogenes in macrophages activated by IFN- $\gamma$ and lipopolysaccharide (LPS).

\section{Materials and methods}

\section{Bacteria}

A laboratory stock culture of $L$. monocytogenes EGD, a virulent strain, was used throughout. The bacteria were grown in Tryptic Soy Broth (Difco) at $37^{\circ} \mathrm{C}$ for $16 \mathrm{~h}$, washed repeatedly, suspended in phosphate-buffered saline and stored at $-70^{\circ} \mathrm{C}$ until use.

\section{Reagents}

Superoxide dismutase and $N^{\mathrm{G}}$-monomethyl-L-arginine (NMMA) were purchased from Wako Pure Chemical Inc. (Osaka, Japan). Recombinant murine IFN- $\gamma$ was provided by the Central Research Institute, Daiichi 
Seiyaku Co. Ltd (Tokyo, Japan). LPS (Escherichia coli 0111:B4) was purchased from Difco. Gentamicin reagent solution was purchased from Life Technologies Inc. (Grand Island, NY, USA).

\section{Cell-free culture of bacteria}

L. monocytogenes was cultured in RPMI 1640 (Flow Laboratories Inc., Maclean, VA, USA) supplemented with various concentrations of gentamicin for $8 \mathrm{~h}$. Every $2 \mathrm{~h}$, the number of survivors $(\mathrm{cfu} / \mathrm{ml})$ was assessed by subcultivation on Brain Heart Infusion (BHI) Agar (Eiken Chemical Co. Ltd, Tokyo, Japan).

\section{Preparation of macrophages}

Male mice (7-10 weeks old) of ICR strain (Charles River Japan, Atsugi, Japan), raised and maintained under specific pathogen-free conditions, were used. Peritoneal exudate cells were obtained from the mice 3 days after intraperitoneal injection of $2 \mathrm{ml}$ of Thioglycollate Medium (Difco) 3\%. The cells were washed with Hanks's Balanced Salts Solution (HBSS) and suspended in the medium consisting of RPMI 1640 supplemented with heat-inactivated fetal bovine serum $10 \%$, gentamicin $10 \mathrm{mg} / \mathrm{L}$, HEPES $5 \mathrm{~g} / \mathrm{L}$ and $\mathrm{NaHCO}_{3}$ $2 \mathrm{~g} / \mathrm{L}$. Peritoneal exudate cells $\left(2 \times 10^{6}\right)$ were cultured in a 24-well flat-bottomed tissue culture plate (Coster, Cambridge, MA, USA) for $2 \mathrm{~h}$ at $37^{\circ} \mathrm{C}$; non-adherent cells were removed by gentle washings with warm HBSS, and the culture medium in each well was replaced with $1 \mathrm{ml}$ of fresh medium. Adherent cells thus prepared were used as macrophages. The cells were stimulated with murine rIFN- $\gamma(100 \mathrm{U} / \mathrm{ml})$ and LPS $(10 \mathrm{mg} / \mathrm{L})$ for $20 \mathrm{~h}$ before use in the intracellular killing assay. After culture for $20 \mathrm{~h}$ the culture medium was replaced with antibiotic-free medium.

\section{Intracellular killing assay}

The procedure is shown in Fig. 1. Macrophages were infected with $L$. monocytogenes at a ratio of $5: 1$ bacteria:cell. The plates were centrifuged at $450 \mathrm{~g}$ for 5 min to enhance the attachment of bacteria to macrophages and incubated at $37^{\circ} \mathrm{C}$ for $60 \mathrm{~min}$ to facilitate the ingestion of bacteria. Extracellular bacteria were removed by washing seven times with $1 \mathrm{ml}$ of warm HBSS, and gentamicin was then added to the culture medium to achieve a concentration of $5 \mathrm{mg} / \mathrm{L}$ unless otherwise stated. Four hours later $(0$ time), counts (cfu) of viable intracellular bacteria were estimated by serial dilution and plating on $\mathrm{BHI}$ agar after disruption of the cells with sterile distilled water to release the intracellular bacteria. After a further $2 \mathrm{~h}$, the number of viable bacteria inside cells was counted again and the difference was regarded as the level of macrophage killing activity. The number of viable bacteria remaining extracellularly was similarly estimated by subculture of washed ( 20 times in HBSS) survivors in supernates of the macrophage assay plates.

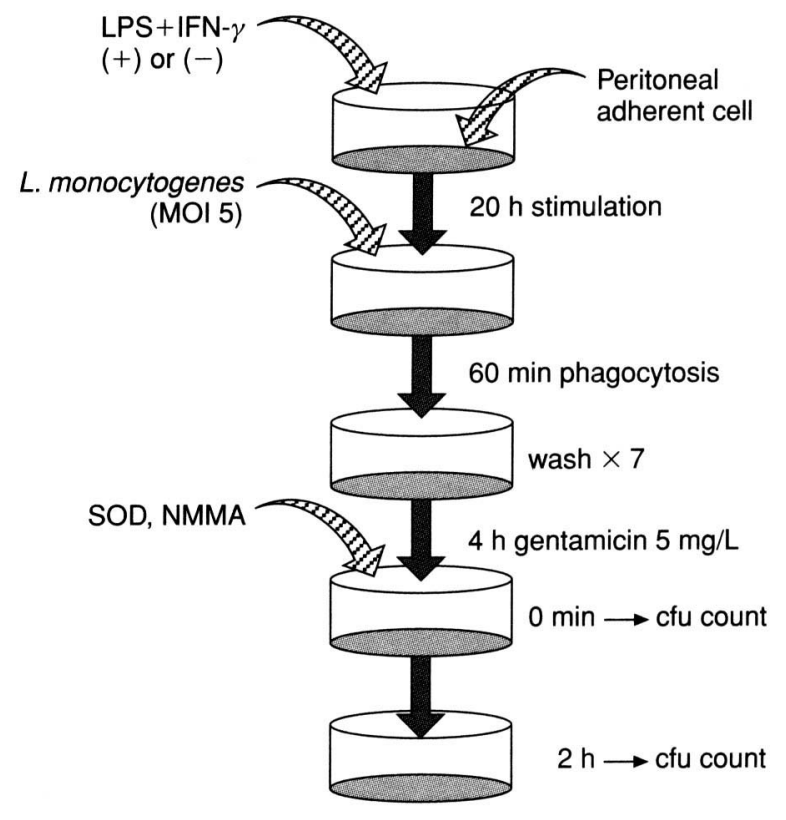

Fig. 1. Experimental procedure for the investigation of intracellular killing of $L$. monocytogenes. MOI, multiplicity of infection; SOD, superoxide dismutase.

\section{Nitrite determination}

Nitrite concentration in the macrophage culture was used as a measurement of nitric oxide synthesis. It was assayed by a standard Griess reaction adapted to microplates as described previously [16]. A 100- $\mu 1$ volume of Griess reagent (equal volumes of sulphanilamide, $1.5 \%$ in $\mathrm{H}_{3} \mathrm{PO}_{4} \quad 5 \%$ and naphthylethylene diamine dihydrochloride, $0.1 \%$ in $\mathrm{H}_{2} \mathrm{O}$ ) was mixed with an equal volume of test sample (culture supernate) and incubated at room temperature for $10 \mathrm{~min}$. Absorbance of the chromophore formed was measured at $540 \mathrm{~nm}$ in an automated microplate reader. Nitrite was quantified with $\mathrm{NaNO}_{2}$ as a standard and the results were expressed as $\mu \mathrm{M}$ of nitrite.

\section{Accumulation of gentamicin inside macrophages}

Peritoneal macrophages were exposed to various concentrations of gentamicin during stimulation with IFN- $\gamma$ and LPS as described above. The cells were harvested and centrifuged. The culture medium was discarded, then the cells were resuspended in $2 \mathrm{ml}$ of HBSS and transferred to a new tube for further washing. The cells were washed twice more with $2 \mathrm{ml}$ of HBSS, and the cell lysate was prepared by ultrasonication for assay of gentamicin. Gentamicin concentration was determined by reverse-phase highperformance liquid chromatography (HPLC) as follows: an L-column ODS $(4.6 \times 150 \mathrm{~mm}, 5 \mu \mathrm{m}$ particle size; Chemicals Inspection and Testing Institute, Tokyo, Japan) maintained at $40^{\circ} \mathrm{C}$ was used as the analytical column. The mobile phase $(0.65 \mathrm{M} \mathrm{NaClO}, 0.04 \mathrm{M}$ $\mathrm{NaH}_{2} \mathrm{PO}_{4}, 0.007 \mathrm{M} m$-xylenesulphonic acid sodium salt and acetonitrile $4.3 \%$ ) was used at a flow rate of $1.5 \mathrm{ml} / \mathrm{min}$. The injection volume was $100 \mu \mathrm{l}$, and fluorescence intensity produced by the reaction of $o$ - 
phthalaldehyde ( $\mathrm{pH}$ 10.5) was measured with excitation set at $340 \mathrm{~nm}$ and emission at $435 \mathrm{~nm}$. The protein concentration of cell lysate was calculated according to the absorbance at $280 \mathrm{~nm}$ and $260 \mathrm{~nm}$.

\section{Results}

Effect of gentamicin on the killing of

\section{L. monocytogenes}

In cell-free culture, gentamicin at concentrations above $3 \mathrm{mg} / \mathrm{L}$ killed $99 \%$ of the bacteria within $4 \mathrm{~h}$ (Fig. 2). In cell culture, gentamicin $5 \mathrm{mg} / \mathrm{L}$ had no influence on

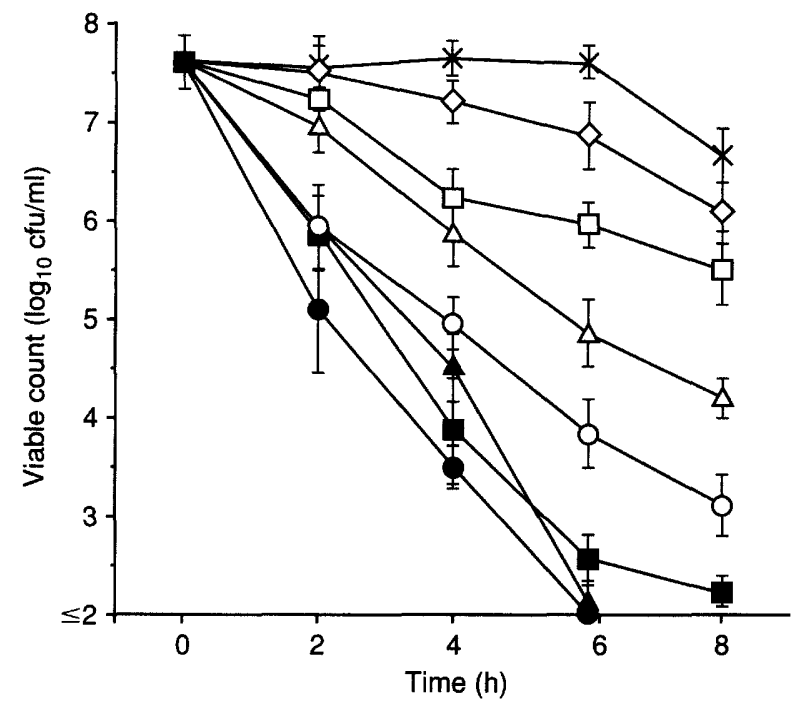

Fig. 2. Effect of gentamicin on the survival of $L$. monocytogenes in a cell-free medium (mean and SD of three experiments). $\times, 0.2 \mathrm{mg} / \mathrm{L} ; \diamond, 0.39 \mathrm{mg} / \mathrm{L} ; \square$, $0.78 \mathrm{mg} / \mathrm{L} ; \triangle, 1.56 \mathrm{mg} / \mathrm{L} ; \bigcirc, 3.125 \mathrm{mg} / \mathrm{L} ; \mathbf{\square}, 6.25 \mathrm{mg} / \mathrm{L}$; $\Delta, 12.5 \mathrm{mg} / \mathrm{L} ; \boldsymbol{\ominus}, 25 \mathrm{mg} / \mathrm{L}$.

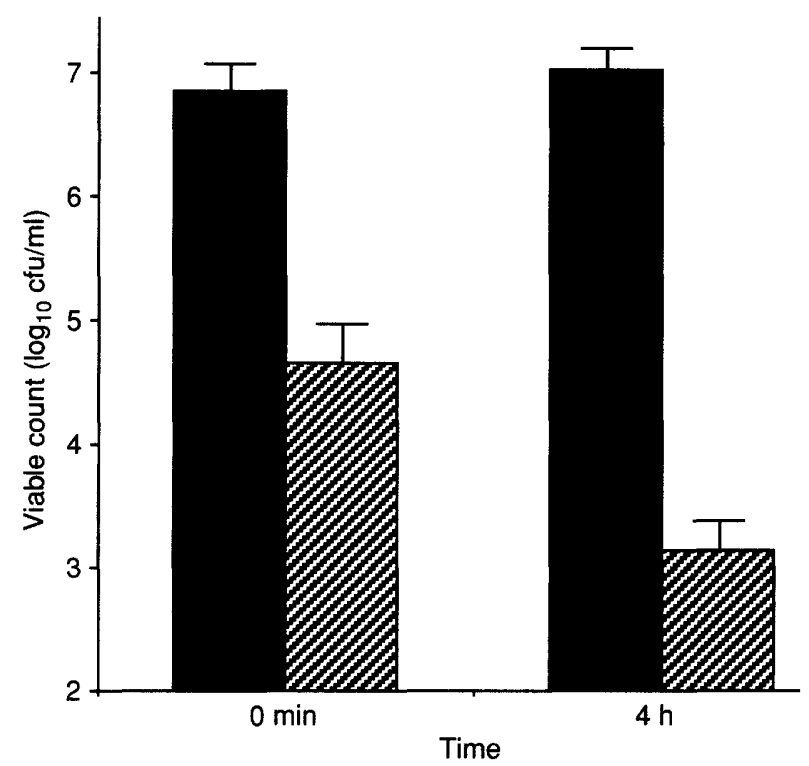

Fig. 3. Counts of $\square$ intracellular and $\oslash$ extracellular bacteria before and after exposure of infected peritoneal macrophages to gentamicin $5 \mathrm{mg} / \mathrm{L}$ for $4 \mathrm{~h}$ (mean and SD of three experiments). the number of bacteria inside macrophages, whereas the number of viable extracellular bacteria was reduced considerably (Fig. 3). After pre-incubation of infected macrophages with gentamicin $5 \mathrm{mg} / \mathrm{L}$ for $4 \mathrm{~h}$, subsequent exposure of the washed cells to gentamicin at concentrations $\leqslant 5 \mathrm{mg} / \mathrm{L}$ had little effect on the growth of $L$. monocytogenes inside macrophages, but concentrations $\geqslant 10 \mathrm{mg} / \mathrm{L}$ reduced intracellular survival (Fig. 4). Assay of gentamicin in cell lysates showed that the intracellular level of gentamicin was increased in a dose-dependent way when the extracellular level was increased (Fig. 5). There was no significant difference in the gentamicin levels inside non-activated macrophages and those activated with IFN- $\gamma$ and LPS (Fig. 5).

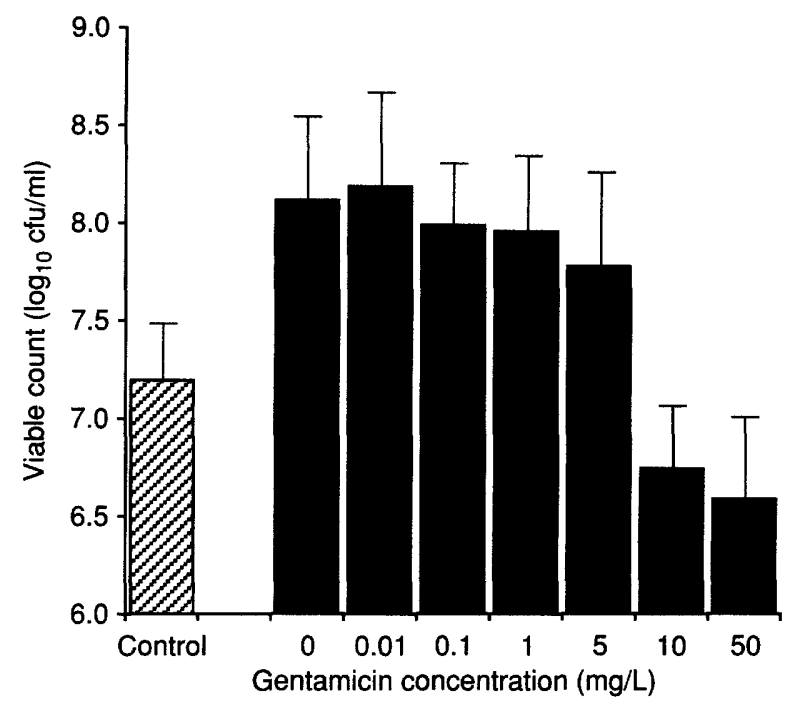

Fig. 4. Effect of exposure for $2 \mathrm{~h}$ to various concentrations of gentamicin on intracellular killing of $L$. monocytogenes after pre-incubation with gentamicin $5 \mathrm{mg} / \mathrm{L}$ for $4 \mathrm{~h}$ (mean and SD of three experiments).

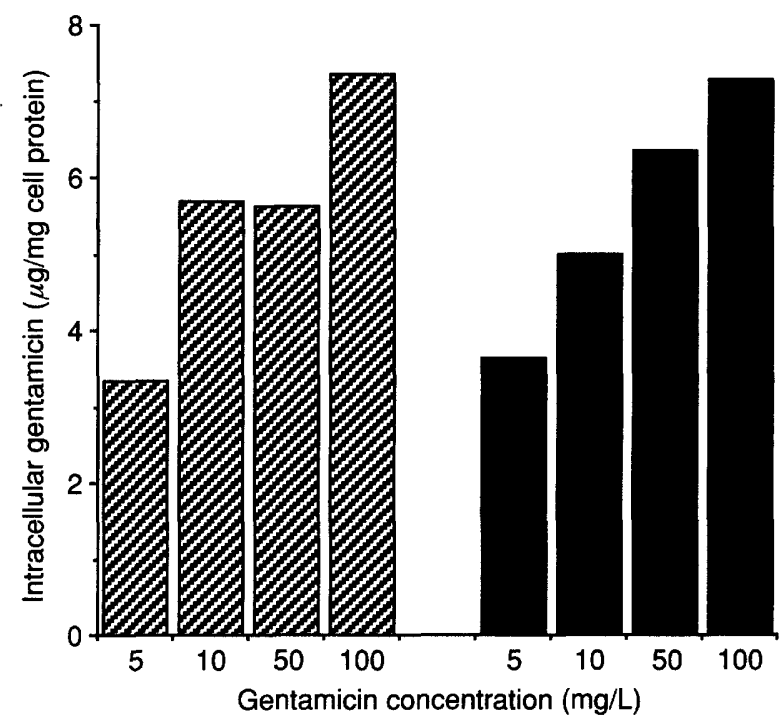

Fig. 5. Intracellular gentamicin concentrations in $\square$ normal and activated macrophages as measured by reverse-phase HPLC of cell lysates, after exposure of cells to gentamicin at the concentrations shown. 
Effect of superoxide dismutase and NMMA on the intracellular survival of $L$. monocytogenes in activated macrophages

Stimulation of macrophages with IFN- $\gamma$ and LPS resulted in the enhancement of listericidal activity in the present assay system, but the listericidal activity of activated macrophages was impaired after addition of superoxide dismutase (Fig. 6). When macrophages were treated with IFN $-\gamma$ and LPS, a large amount of nitrite was produced, but after the addition of NMMA, nitrite production was inhibited (data not shown). However, NMMA did not impair the listericidal activity of macrophages stimulated with IFN- $\gamma$ and LPS (Fig. 7).

\section{Discussion}

Macrophages are the most important effector cells in the defence of the host against infection by intracellular bacteria including $L$. monocytogenes. A reliable assay system for the intracellular killing activity of macrophages is of critical importance, especially for the understanding of mechanisms for the expression of protective immunity. One of the key requirements for the accuracy of the in-vitro bactericidal assay is to eliminate the bacteria remaining extracellularly after ingestion by macrophages. For this purpose, gentamicin at a concentration of $c .50 \mathrm{mg} / \mathrm{L}$ has been widely used, as this antibiotic is believed to be incapable of penetrating the macrophage membrane. However, there are reports that such a high concentration of gentamicin penetrates $\mathrm{HeLa}$ cells, reaching c. $90 \%$ of the extracellular concentration after incubation for $72 \mathrm{~h}$

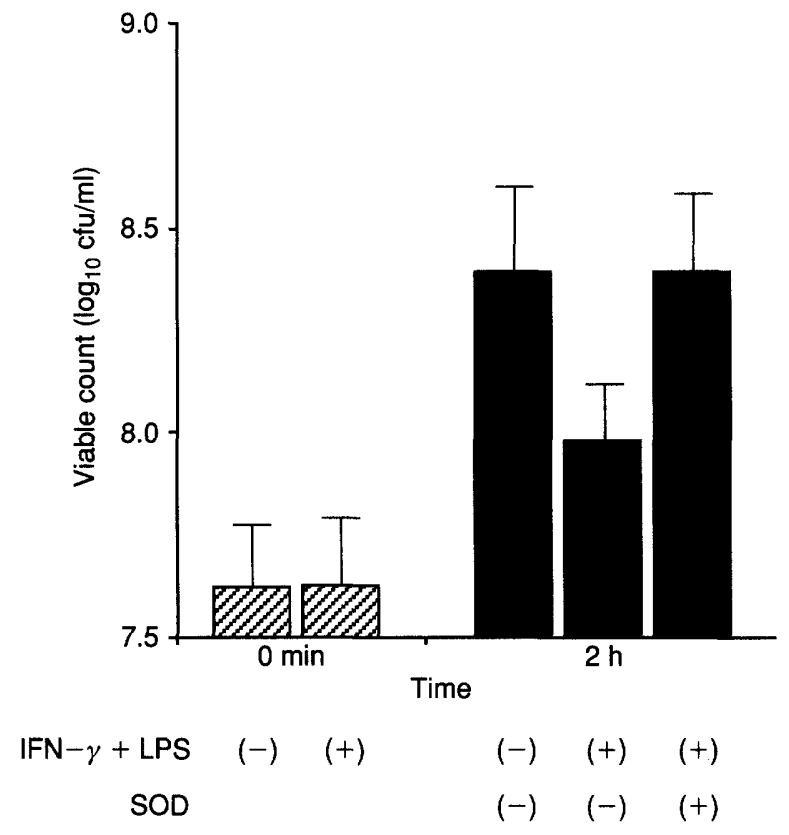

Fig. 6. Effect of superoxide dismutase (SOD) on the intracellular growth of $L$. monocytogenes in macrophages pretreated with IFN- $\gamma$ and LPS (mean and SD of three experiments).

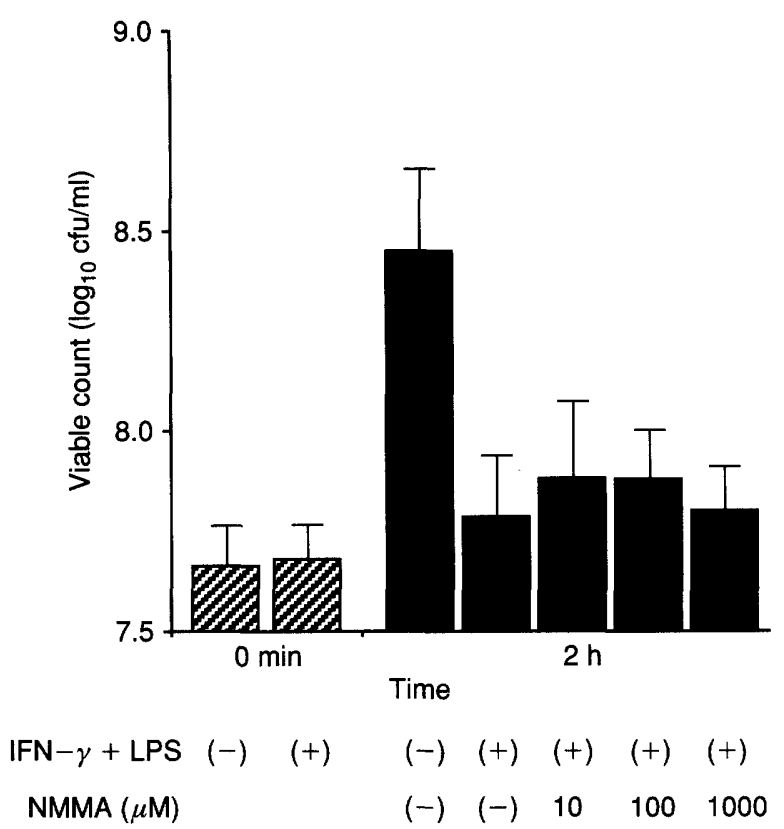

Fig. 7. Effect of NMMA on the intracellular growth of $L$. monocytogenes in macrophages pretreated with IFN- $\gamma$ and LPS (mean and SD of three experiments).

[17]. Drevets et al. [15] also showed that extracellular gentamicin, used at $50-100 \mathrm{mg} / \mathrm{L}$, could accumulate within macrophages and pointed out that the use of gentamicin in macrophage bactericidal assays might result in an incorrect interpretation of experimental results.

The present study tried to establish a reliable assay system with special reference to the concentration of gentamicin that effectively kills extracellular bacteria without affecting growth of intracellular L. monocytogenes. The results (Figs. 3 and 4) suggest that $5 \mathrm{mg} / \mathrm{L}$ of gentamicin is a suitable concentration to use in the intracellular bactericidal assay. However, this concentration may affect intracellular $L$. mono-

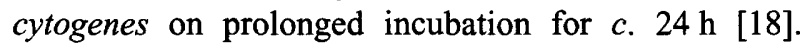
Accordingly, when a longer observation time is required, the cells should be cultured in gentamicin at a concentration $<5 \mathrm{mg} / \mathrm{L}$ after eliminating extracellular bacteria. The use of a higher concentration of gentamicin resulted in the accumulation of antibiotic inside cells (Fig. 5).

Incubation of macrophages in the presence of recombinant IFN- $\gamma$ and LPS resulted in enhanced intracellular killing of $L$. monocytogenes in the present assay system. Measurement of intracellular gentamicin revealed that this was not due to an enhanced uptake of antibiotic as postulated by Drevets et al. [15]. Macrophages stimulated with IFN- $\gamma$ and LPS exhibit an enhanced generation of $\mathrm{O}_{2}^{-}$. In the present system, when $\mathrm{O}_{2}^{-}$production was inhibited by adding superoxide dismutase, the killing ability of activated macrophages was impaired (Fig. 6). The results confirmed that $\mathrm{O}_{2}^{-}$was involved in the killing of $L$. 
monocytogenes by activated macrophages and confirmed the reliability of the present assay system.

Nitric oxide is a toxic radical synthesised from Larginine by inducible nitric oxide synthase which is expressed mainly in activated cells of macrophage lineage [19]. IFN- $\gamma$ and LPS are potent inducers of nitric oxide synthase in macrophages [19]. Nitric oxide exhibits antimicrobial activity in vitro against various pathogens, such as Leishmania major [20], Toxoplasma gondii [21] and Mycobacterium bovis [22], and may be a critical effector molecule in the killing of $L$. monocytogenes by IFN- $\gamma$-activated macrophages [23], although reports are conflicting [24-26]. In the present study, when peritoneal macrophages were stimulated with IFN- $\gamma$ and LPS, a large amount of nitric oxide was observed as determined by nitrite in the supernates of the culture (data not shown). Surprisingly, there was no change in the killing function of activated macrophages even in the presence of NMMA, which completely inhibited the production of nitrite (Fig. 7). These data do not support a primary role for nitric oxide in the killing of intracellular $L$. monocytogenes in macrophages preactivated by IFN- $\gamma$ and LPS in vitro. The results suggest that the reactive oxygen radicals were more important than nitric oxide in the killing of $L$. monocytogenes in these conditions.

This study was supported by grants-in-aid for scientific research from the Ministry of Education, Science, Culture and Sports, and the Ministry of Health and Welfare, Japan. We are grateful to the Central Research Institute, Daiichi Seiyaku Co. Ltd (Tokyo, Japan), for providing murine recombinant IFN- $\gamma$.

\section{References}

1. Gaillard J-L, Berche P, Mounier J, Richard S, Sansonetti P. In vitro model of penetration and intracellular growth of Listeria monocytogenes in the human enterocyte-like cell line Caco-2. Infect Immun 1987; 55: 2822-2829.

2. Kuhn M, Kathariou S, Goebel W. Hemolysin supports survival but not entry of the intracellular bacterium Listeria monocytogenes. Infect Immun 1988; 56: 79-82.

3. Kathariou S, Pine L, George V, Carlone GM, Holloway BP. Nonhemolytic Listeria monocytogenes mutants that are also noninvasive for mammalian cells in culture: evidence for coordinate regulation of virulence. Infect Immun 1990; 58: 3988-3995.

4. Gaillard J-L, Berche P, Frehel C, Gouin E, Cossart P. Entry of L. monocytogenes into cells is mediated by internalin, a repeat protein reminiscent of surface antigens for gram-positive cocci. Cell 1991; 65: 1127-1141.

5. Köhler S, Bubert A, Vogel M, Goebel W. Expression of the iap gene coding for protein p60 of Listeria monocytogenes is controlled on the posttranscriptional level. J Bacteriol 1991; 173: 4668-4674.

6. Cossart P, Vicente MF, Mengaud J, Baquero F, Perez-Diaz JC, Berche P. Listeriolysin $\mathrm{O}$ is essential for virulence of Listeria monocytogenes: direct evidence obtained by gene complementation. Infect Immun 1989; 57: 3629-3636.

7. Nishibori T, Cooray K, Xiong H, Kawamura I, Fujita M, Mitsuyama M. Correlation between the presence of virulenceassociated genes as determined by PCR and actual virulence to mice in various strains of Listeria spp. Microbiol Immunol 1995; 39: 343-349.

8. Kaufmann SHE. Acquired resistance to facultative intracellular bacteria: relationship between persistence, cross-reactivity at the T-cell level, and capacity to stimulate cellular immunity of different Listeria strains. Infect Immun 1984; 45: 234-241.

9. Czuprynski CJ, Henson PM, Campbell PA. Enhanced accumulation of inflammatory neutrophils and macrophages mediated by transfer of $\mathrm{T}$ cells from mice immunized with Listeria monocytogenes. J Immunol 1985; 134: 3449-3454.

10. Portnoy DA, Schreiber RD, Connelly P, Tilney LG. $\gamma$ Interferon limits access of Listeria monocytogenes to the macrophage cytoplasm. $J$ Exp Med 1989; 170: 2141-2146.

11. Nathan CF, Murray HW, Wiebe ME, Rubin BY. Identification of interferon- $\gamma$ as the lymphokine that activates human macrophage oxidative metabolism and antimicrobial activity. $J$ Exp Med 1983; 158: 670-689.

12. Martin JH, Edwards SW. Interferon- $\gamma$ enhances monocyte cytotoxicity via enhanced reactive oxygen intermediate production. Absence of an effect on macrophage cytotoxicity is due to failure to enhance reactive nitrogen intermediate production. Immunology 1994; 81: 592-597.

13. Nathan CF, Hibbs JB. Role of nitric oxide synthesis in macrophage antimicrobial activity. Curr Opin Immunol 1991; 3: $65-70$.

14. $\mathrm{Xu} \mathrm{S}$, Cooper $\mathrm{A}$, Sturgill-Koszycki $\mathrm{S}$ et al. Intracellular trafficking in Mycobacterium tuberculosis and Mycobacterium avium-infected macrophages. J Immunol 1994; 153: 25682578.

15. Drevets DA, Canono BP, Leenen PJM, Campbell PA. Gentamicin kills intracellular Listeria monocytogenes. Infect Immun 1994; 62: 2222-2228.

16. Xiong H, Kawamura I, Nishibori T, Mitsuyama M. Suppression of IFN- $\gamma$ production from Listeria monocytogenes-specific $\mathrm{T}$ cells by endogenously produced nitric oxide. Cell Immunol 1996; 172: 118-125.

17. Brown KB, Percival A. Penetration of antimicrobials into tissue culture cells and leucocytes. Scand J Infect Dis 1978; Suppl 14: $251-260$.

18. Michelet C, Avril JL, Cartier F, Berche P. Inhibition of intracellular growth of Listeria monocytogenes by antibiotics. Antimicrob Agents Chemother 1994; 38: 438-446.

19. Nussler AK, Billiar TR. Inflammation, immunoregulation, and inducible nitric oxide synthase. J Leukoc Biol 1993; 54: 171178.

20. Liew FY, Millott S, Parkinson C, Palmer RMJ, Moncada S. Macrophage killing of Leishmania parasite in vivo is mediated by nitric oxide from L-arginine. $J$ Immunol 1990; 144: 47944797.

21. Adams LB, Hibbs JB, Taintor RR, Krahenbuhl JL. Microbiostatic effect of murine-activated macrophages for Toxoplasma gondii. Role for synthesis of inorganic nitrogen oxides from Larginine. J Immunol 1990; 144: 2725-2729.

22. Flesch IEA, Kaufmann SHE. Mechanisms involved in mycobacterial growth inhibition by gamma interferon-activated bone marrow macrophages: role of reactive nitrogen intermediates. Infect Immun 1991; 59: 3213-3218.

23. Beckerman KP, Rogers HW, Corbett JA, Schreiber RD, McDaniel ML, Unanue ER. Release of nitric oxide during the $T$ cell-independent pathway of macrophage activation. Its role in resistance to Listeria monocytogenes. J Immunol 1993; 150: $888-895$.

24. Leenen PJM, Canono BP, Drevets DA, Voerman JSA, Campbell PA. TNF- $\alpha$ and IFN- $\gamma$ stimulate a macrophage precursor cell line to kill Listeria monocytogenes in a nitric oxideindependent manner. J Immunol 1994; 153: 5141-5147.

25. Inoue S, Itagaki S-I, Amano F. Intracellular killing of Listeria monocytogenes in the J774.1 macrophage-like cell line and the lipopolysaccharide (LPS)-resistant mutant LPS1916 cell line defective in the generation of reactive oxygen intermediates after LPS treatment. Infect Immun 1995; 63: 1876-1886.

26. Samsom JN, Langermans JAM, Groeneveld PHP, van Furth R. Acquired resistance against a secondary infection with Listeria monocytogenes in mice is not dependent on reactive nitrogen intermediates. Infect Immun 1996; 64: 1197-1202. 